\title{
ASIA PUBLISHING HOUSE
}

Diese Stelle der Zeitschrift, an der sich bisher die an der Herausgabe beteiligten Institute vorgestellt haben, soll der Information über Einrichtungen gewidmet sein, die für die Übersee-Forschung wichtig sind.

Diesmal geben wir einem bedeutenden Verlagshaus der Dritten Welt Gelegenheit zur Selbstanzeige.

At first glance, 1943, may seem an unlikely year for the birth of an international publishing house in India. It was a year after the "Quit India"-campaign against British rule, a time when nationalism was reaching its crest. Yet even in the midst of these stirring but uncertain times there were people in India who saw not only the country's independence within a short time, but also that of other Asian countries as highly imminent and that, within a short time these independent nations would enter the world stage at a crucial juncture. Independence would bring not only international prominence and responsibility but also, and perhaps more urgently, national reconstruction. One such far-seeing person was Mr. P. S. Jayasinghe who founded the Asia Publishing House in Bombay in October 1943.

Anyone interested in serious books on the Third World and its problems, is by now familiar with the Asia Publishing House imprint. Asia books are issued from three Continents - Bombay, London and New York. Interestingly enough, this is not a case of a firm which got into international publishing at a late stage but an instance of a firm which, from the start, was designed for an international role. The basic aim of the firm from the start has been to act as a link between not only India but also Asia on the one hand and Europe and America on the other. Until then and indeed more or less from the beginning of European conquests in Asia, the flow of information and ideas had been nearly always and exclusively one way - from the West to Asia, and almost none the other way round. A special reason for the founding of Asia Publishing House was to provide an authentic view of India - past and present, to the rest of the world. Perhaps inevitably, the years of European rule in India and elsewhere produced a grossly distorted, frequently patronising, view of this large mass of humanity, whose civilization goes back milleniums beyond that of Europe. Many educated Asians could not recognize their countries as described in many of the popular books of the time. Unless this state of affairs was improved radically and rapidly, the newly independent countries would not be able to play the roles opened to them by the coming of independence. In case of countries like India, colonial rule had gone on so long that the wrong image of their own history and culture had penetrated the minds of several generations. This had to be changed. Equally, the people had to be given a balanced view of the rest of the world as well in the place of the long tradition of glorifying the European nation which happened to have ruled one of these countries.

As was to be expected, Asia Publishing House began by publishing books by outstanding Indian scholars dealing with history, sociology, politics, law and other disciplines. At the same time, the educational needs and indeed those of the modernisation of the country were not neglected. From an early stage, the firm has published inexpensive editions of standard textbooks and other important reference works from the West in India for use by students and professional people in all walks of life.

The first twenty-five years of the publishing house's growth show three distinct stages in which it responded to the changing world and its needs, so far as serious literature is concerned. The first decade from the mid 1940s to the mid 1950s saw the firm's rapid entry into full-scale publishing. A large number of books on 
ancient history as well as the independence movement, the current political issues of newly independent India and educational books, dominated the publishing programme of the period. The first decade also marked a major breakthrough in the Indian book trade. Concurrently with the publication of its own books as well as reprints of British and American books, the company also actively promoted the readership of the latest scientific and technical books published in Europe and America. It must be remembered that it was during this period - immediately after independence - that India made a major switch in educational policy favouring technical education.

The second stage of the growth of the company began in the middle 1950s. During this time, it began to extend both its publishing programme and its own operations beyond the confines of India. The London and New York Offices were opened in 1959. During this period an increasing number of books were published not only by scholars from other countries of Asia and Africa, but also by British, French, German and American authors. Notable among these books are GOVERNMENT AND POLITICS IN AFRICA by T. O. Elias, the then Attorney General and Minister of Justice of Nigeria, Prof. J. C. de Graft Johnson's AN INTRODUCTION TO THE AFRICAN ECONOMY, PROSPERITY THROUGH COMPETITION by Dr. Ludwig Erhard, the former Chancellor of the Federal Republic of Germany, J. K. Galbraith's THE AFFLUENT SOCIETY, Paul Appleby's PUBLIC ADMINISTRATION FOR THE WELFARE STATE, Charles Bettelheim's STUDIES IN THE THEORY OF PLANNING and many others of this calibre. Another important event during this period was the publication of A BUNCH OF OLD LETTERS by the then Prime Minister of India, Mr. Jawaharlal Nehru, the only book which he produced after independence; his earlier books written in prison, THE DISCOVERY OF INDIA, GLIMPSES OF WORLD HISTORY, are also published by Asia.

During the 60s, the publishing programme has been expanded further to encompass the work of outstanding scientists and engineers from India, who have ideas and knowledge to share with the rest of the world. A number of these books, for example PULSE CIRCUITS by B. Chatterjee, MODERN METHODS IN STRUCTURAL MECHANICS by B. N. Thadani, have become adopted textbooks in many universities around the world. Equally, the importance of scientific research in the Soviet Union has been recognised and a series of books is being issued with standard works on many disciplines of engineering as seen by Soviet experts.

One other way of looking at Asia's publishing is to identify the main areas which have been specially highlighted throughout. The social sciences, notably sociology, political institutions and processes, law, as well as economical developments, have been consistently the major elements in the programme.

Particularly in the 1950s, the whole world, both developed and developing, looked to India with the greatest interest to see how its experiment in achieving a rapid economical development within a democratic framework would succeed. Some important books covering this process of democratic planning and development have been published.

Connected with the whole question of economic development are the areas of social structure, the need for social change and the establishment of political and legal frameworks within which a full scale effort could be successfully launched. All this particularly in relation to South Asia is very fully covered by Asia's publishing over the years.

A publisher's performances over the period of a quarter century can be best judged by his list of authors and books. A short bibliography of Asia Publishing House publications in the fields of sociology, politics and law follows: 
Sociology

\section{Anderson}

Srinivas

Panikkar

Majumdar

Sullivan

Andre Beteille

Desai

Moddie

Gaikwad

Vidyarthi

Dharan

Our Industrial Urban Civilization

India's Villages

Hindu Society at Crossroads

Races and Cultures of India

Education in Social Change

Castes Old and New

Size and Sex Composition in India 1961

Brahmanical Culture and Modernity

The Anglo-Indians

Leadership in India

You and Your Community

\section{Politics}

Appadorai

Appadorai

Bhaskaran

Mathur

Nagendra Singh

Maung Maung

Moulton

Rajendra Avasthi

Baljit Singh \& Ko Wang Mei

India - Studies in Social and Political Development

Essays in Politics and International Relations

Sociology of Politics
Panchayati Raj - Planning and Democracy

Theory of Force and Organisation of Defence in Indian Constitutional History

Burma and General Ne Win

Lord Northbrook's Indian Administration

Nature of Politics

Theory and Practice of Modern Guerilla Warfare

Law

Anand

Bedi

Consul \& Chandran

Nigam

Hidayatullah

Hingorani

Compulsory Jurisdiction of the International Court of Justice

Freedom of Expression and Security

Advocacy

Law of Crimes in India Volume I

South West Africa Case

The Indian Extradition Law 